\title{
Inovasi Proses Kreatif Rosette Guitar Quartet Di Era New Normal
}

\author{
Kanzul Fikri \\ Prodi Pendidikan Musik, STKIP Citra Bakti Ngada-Flores \\ Email: kanzulfikri91@gmail.com
}

\begin{abstract}
Rosette guitar quartet is a guitar quartet group consisting of four guitar players and on originally the Rosette guitar quartet was performing classical guitar songs arranged in four guitars. Method in this research using an qualitative approach. Qualitative research tries to answer question rather than testing the hypothesis. This research uses creative process theory and innovations theory which consist of 4 types, namely (1) Discovery (2) Extension (3) Duplication (4) Synthesis. The Result of innovation made by Rosette guitar quartet are (1) Invention made by Rosette Guitar is creating a new process in the guitar quartet group perfoming songs in postmodern era and uploaded on social media, such as "Youtube", (2) Development of the Rosette guitar expresses his works in social media, where to adjust the new habits to music enthusiast that can appreciate perfoming of Rosette by virtual. (3) Rosette Guitar duplicate the most successful musicians used to express and maximize each his work in "Youtube" which gets a lot of appreciation (viewers) according to the new normal era. (4) The Rosette guitar perfoms synthesis with create new works every month and uploaded on "Youtube". Collaborative creative process of this synthesis considered by Rosette guitar quartet as great opportunity to music works, expression as well as new innovations in industry creative in the new normal era.
\end{abstract}

Keywords: Innovation, Creative Process, New Normal.

\begin{abstract}
Abstrak: Rosette guitar quartet adalah grup quartet guitar yang terdiri dari empat pemain gitar, dan pada awalnya reosette guitar quartet dalam proses seninya membawakan lagu klasik atau gitar klasik yang diaransemen dalam empat gitar. Metode dalam penelitian ini menggunakan pendekatan kualitatif. Penelitian kualitatif memfokuskan pada data bukan angka, dan berupaya menjawab pertanyaan dari pada menguji hipotesis. Penelitian ini menggunakan teori proses kreatif dan teori inovasi yang terdiri dari 4 jenis, yaitu; (1) Penemuan (Invention) (2) Pengembangan (Extension) (3) Duplikasi (Duplication) (4) Sintesis (Synthesis). Hasil inovasi yang dilakukan oleh Rosette guitar quartet adalah (1) Penemuan yang dilakukan oleh Rosette Guitar Quartet yaitu mengkreasikan suatu proses baru dalam grup guitar quartet yang membawakan lagu-lagu pada zaman postmodern dan diunggah di akun sosial media seperti You Tube; (2) Pengembangan Rosette guitar quartet mengkespresikan karyakaryanya dalam sosial media, menyesuaikan kebiasaan baru di mana para penikmat musik bisa mengapresiasi karya dari Rosette secara virtual; (3) Rosette guitar quartet melakukan duplikasi pada musisi yang terlebih dulu berkespresi dan memaksimalkan setiap karyanya dalam You Tube yang mendapat banyak apresiasi (viewers) sesuai kenormalan baru; (4) Rosette guitar quartet melakukan sintesis dengan membuat karya-karya baru tiap bulannya dan diunggah di You Tube. Proses kreatif kolaborasi dari sintesis ini dianggap oleh Rosette Guitar Quartet sebagi peluang besar dalam berkarya, berekspresi, serta inovasi baru dalam berindustri kreatif di era normal baru.
\end{abstract}

Kata Kunci: Inovasi, Proses Kreatif, Normal Baru

\section{Article info:}

Received: 29 November 2020

Reviewed: 03 Desember 2020

Accepted: 30 Juni 2021

\section{PENDAHULUAN}

Gitar klasik merupakan instrumen yang memiliki dawai atau string dan diciptakan pertama kali pada zaman klasik untuk memainkan reportoire yang tercipta pada zaman tersebut. Nada yang dihasilkan oleh gitar klasik tidak hanya melodi tunggal tetapi juga harmonis atau suara yang lebih dari satu atau maksimal enam suara, seperti chord bahkan kombinasi antar chord dan melodi.

Birul Walidaini (2020) menjelaskan salah satu aktivitas bermusik ialah pementasan, dalam konteks gitar klasik yang dimaksud adalah pementasan dengan memainkan alat musik gitar dan membawakan repertoar standar untuk gitar klasik. Pementasan tersebut dilakukan tidak 
hanya pada era klasik tetapi juga di era modern dan postmodern.

Pada era modern atau postmodern, instrumen gitar klasik tidak hanya membawakan repertoire pada zaman klasik tetapi juga membawakan lagu-lagu baru yang diaransemen atau ditranskip ke dalam bentuk tunggal maupun grup. Dalam postmodern, pandangan seni modern universalisme merupakan landasan atau fundamental dalam bidang seni, sedangkan pandangan post-modern menekankan pada pemberian rasa hormat dan penghargaan akan adanya perbedaan-perbedaan dan adanya keragaman serta kontradiksi dalam bidang seni. Seni aliran postmodern selalu mengetengahkan karakter atau ciri khas seperti unsur campur baur (eklektisme). Selain merujuk pada era modern dan postmodern yang telah dialami, muncul lagi era new normal atau disebut normal baru, dimana era ini muncul karena akibat dari Covid19 (corona virus disease 2019). Covid-19 ini mengakibatkan kebiasaan aktifitas lama yang dilakukan menjadi banyak perubahan, mulai dari jaga jarak antara manusia, memakai masker, dan lain sebagainya sesuai protokol kesehatan, agar terhindar dari Covid-19.

Banyak peneliti mendeskripsikan, bahwa kebiasaan yang terus-menerus dilakukan akan menjadi kebiasaan baru, seperti halnya yang disampaikan oleh Dr. Maxwell Maltz dari buku Psychocybernetics, bahwa 21 hari untuk membentuk kebiasaan baru (Maltz, 2015). Kegiatan atau aktifitas baru ini dilakukan terus menerus pada semua sektor baik dari dunia kerja, pendidikan, bahkan dari bidang kesenian, juga ikut serta menyesuaikan dan mengikuti kenormalan baru ini, salah satunya yaitu dalam pertunjukan musik.

Salah satu bentuk realita yang bisa dijumpai saat ini adalah munculnya pertunjukan musik virtual, dengan menggunkan media sosial seperti; Instagram dan Yuotube. Banyak dikalangan musisi yang memanfaatkan media ini untuk mengkespresikan karya seni musik dalam bentuk virtual yang bisa diakses secara online di rumah sesuai protokol kesehatan atau kenormalan baru (New Normal). Avanti Fontana (2011) menjelaskan inovasi sebagai keberhasilan ekonomi berkat adanya pengenalan cara baru atau kombinasi baru dari cara-cara lama dalam mentransformasi input menjadi output (teknologi) yang menghasilkan perubahan besar atau drastis dalam perbandingan antara lain guna yang dipersepsikan oleh konsumen atas manfaat suatu produk (barang dan/atau jasa) dan harga yang ditetapkan oleh produsen. Selain itu, Rakhmat Harjono (2018) juga menjelaskan tentang proses kreatif, bahwa proses kreatif lebih ditempatkan sebagai salah satu aspek dari orang kreatif bukan kreteria yang berdiri sendiri.

Apa yang dijelaskan oleh Avanti Fontana dan Rakhmat Harjono sesuai dengan apa yang dilakukan oleh banyak musisi Indonesia yakni memanfaatkan teknologi atau media sosial sebagai inovasi dan proses kreatif untuk melakukan pertunjukan secara virtual, seperti Jubing Kristanto, Tohpati, Dewa 19, Gigi, Ari Lasso, dan masih banyak lagi yang lain. Bukan hanya itu, para musisi indie yang tidak memiliki label juga bisa bebas berkspresi dalam pertunjukan musik secara virtual, salah satunya yakni grup musik gitar asal Surabaya yaitu Rosette Guitar Quartet yang akan menjadi topik pembahasan dalam artikel ini.

\section{METODE}

Penelitian ini menggunakan pendekatan kualitatif. Penelitian kualitatif memfokuskan pada data, bukan angka, dan berupaya menjawab pertanyaan daripada menguji hipotesis. Kehadiran peneliti pada penelitian kualitatif merupakan suatu keharusan, karena penelitian kualitatif lebih mengutamakan temuan observasi terhadap berbagai fenomena yang ada ataupun wawancara yang dilakukan peneliti sendiri sebagai instrumen penelitian.

Melalui data kualitatif, dapat mengikuti dan memahami alur peristiwa secara kronologis, menilai sebab akibat, khususnya peneliti berusaha untuk mendeskripsikan data tentang inovasi proses kreatif di era new normal oleh Rosette guitar quartet.

Sumber data manusia yaitu narasumber yang merupakan pemain atau anggota dari Rosette Guitar Quartet, yaitu Danang, Almas, dan Laukhy. Sumber data non-manusia meliputi data-data yang berkaitan dengan objek penelitian, diantaranya adalah dokumen foto, video, serta kegiatan Rosette Guitar Quartet ketika performance, yang berkaitan dengan proses kreatifnya dengan menggunakan sosial media.

Sugiyono menjelaskan bahwa teknik pengumpulan data merupakan langkah yang paling strategis dalam penelitian, karena tujuan utama dari penelitian adalah mendapatkan data (2011:224). Pengumpulan data penelitian tentang Rosette guitar quartet menggunakan metode observasi, wawancara, dan dokumentasi. 
Peneliti secara langsung melihat pertunjukan dan instrumen yang digunakan dengan menggunakan alat bantu berupa alat rekam kamera dan video. Peneliti mengamati secara langsung proses latihan dan rekaman video Rosette guitar quartet, agar penulis dapat mengamati dan mendeskripsikan dalam proses kreatif, repertoire, dan penggunaan sosial media (Youtube dan Instagram) oleh Rosette guitar quartet sebagai sarana dalam proses kreatif dan ekpresi dalam berkarya.

\section{HASIL DAN PEMBAHASAN Rosette Guitar Quartet}

Rosette Guitar Quartet terbentuk pada tahun 2014 di Surabaya. Personil dari group gitar ini terdiri dari mahasiswa Universitas Negeri Surabaya. Keempat mahasiswa tersebut, yaitu Danang Sandy (guitar I), Kanzul Fikri (guitar II), Almas Fadhil (guitar III), Lauhky Hidayat (guitar IV). Pada awal proses seninya Rosette membawakan lagu-lagu atau repertoire klasik yang dimainkan dalam format guitar klasik. Selain itu, tempat berekspresi group guitar ini awalnya di gedung pertunjukan atau gedung resital yang ukurannya lebih kecil.

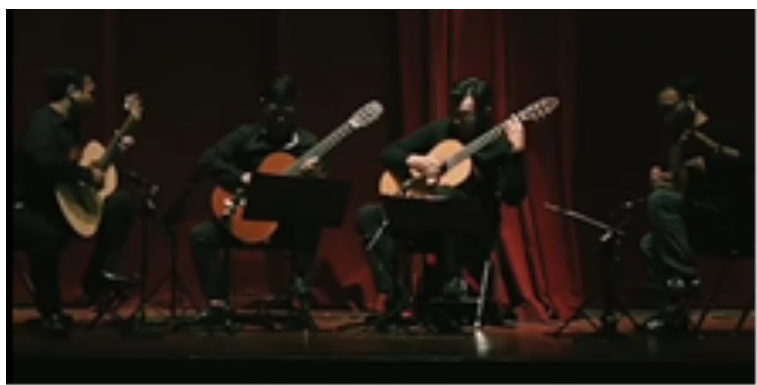

Gambar 1. Performance Rosette Guitar Quartet di Gedung Pertunjukan (dokumentasi: pribadi, 2019)

Dalam era normal baru ini Rosette Guitar Quartet tidak hanya menggunakan gedung pertunjukan atau gedung Recital sebagai tempat berekspresi setiap karya yang dibawakan tetapi memanfaatkan media sosial seperti "Youtube" dan "Instagram" dalam berekspresi di era normal baru. Seperti yang dijelaskan oleh Singgih Rastra (2018) bahwa Instagram, Facebook, Twitter, Youtube sebagai media untuk berkarya serta dapat memperkenalkan diri.

Kecermatan dari grup ini dalam melihat situasi dan kondisi yang ada, serta proses adaptasi yang baik, sehingga terwujudnya hasil yang apik dalam berkarya. Sama halnya yang disampaikan oleh Mei Artanto (2020) bahwa jika penggarapan musik tidak cukup cermat, maka bukan perpaduan apik yang yang dicapai tetapi justru karakter dan identitas musikal dari musik tersebut tidak tersampaikan secara baik kepada pendengar.

Seiring berjalannya waktu, tepatnya di masa pandemi karena covid-19, Rosette guitar quartet mengembangkan proses seninya menjadi lebih kreatif dan lebih berinovasi. Tidak hanya menunggu hingga pandemi ini berakhir dan menghindari kerumunan orang tetapi tetap membawakan lagu aransir quartet guitar melalui media sosial.

\section{Proses Kreatif Rosette Guitar Quartet}

Damajanti (2006) menjelaskan bahwa beberapa menunjuk pada faktor-faktor luar (eksternal) dalam kehidupan seniman. Lainnya terpusat pada kecerdasan seniman. Dorongan naluri yang mendorong para seniman dan ilmuwan berkreasi merupakan pertanyaan yang sering menarik perhatian para psikolog. Seperti halnya yang disampaikan oleh Damajanti, Rosette Guitar Quartet melakukan proses seni yang kreatif yakni :

\section{Repertoire (lagu)}

Dalam pemilihan lagu atau repertoire yang akan diaransemen atau dibawakan, Rosette Guitar Quartet melakukan beberapa tahapan seleksi, yaitu; (1) lagu yang sesuai jika dibawakan pada instrumen gitar klasik, (2) lagu yang sedang trending di media sosial (Youtube), (3) lagu yang akan memiliki penikmat (viewers) yang banyak, serta (4) Focus group discussion secara daring untuk membuat jadwal produksi yang akan dilakukan.

\section{Latihan dan "take audio"}

Dalam tahapan ini, partitur lagu yang sudah diaransemen, akan dibagikan kepada masing-masing pemain (Gitar I, II, III, dan IV) oleh Danang Sandy. Setelah masing-masing pemain mendapatkan partitur musik lagu yang akan digarap, masing-masing pemain mempelajari terlebih dahulu atau melakukan proses latihan sendiri sebelum melakukan rekaman mandiri di rumah. Setelah dirasa cukup latihan dan perekaman mandiri di rumah, berupa audio visual.

\section{Editing}

Proses editing dilakukan setelah semua anggota group dari Rosette Guitar Quartet mengunggah hasil rekaman melalui media google drive yang bisa diakses bersama. Setelah proses unduh video dan audio dilakukan, dan melalui proses mixing dan editing secara kolase oleh Laukhy sebagi editor video. Setelah proses editing selesai, tahap berikutnya yaitu 
penayangan atau mengunggah di media sosial sesuai jadwal tayang yang telah ditentukan.

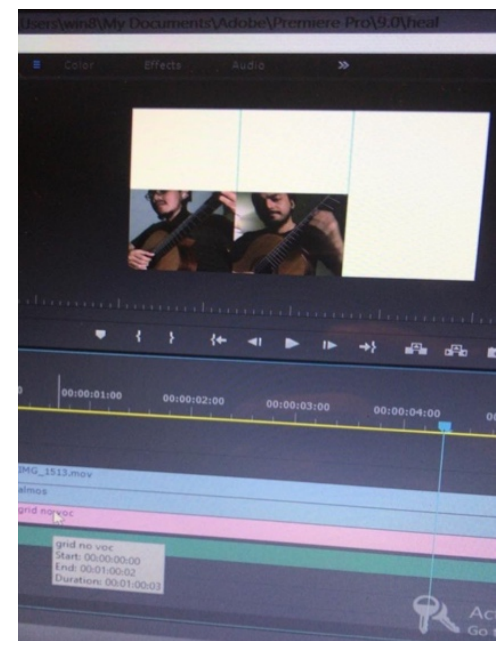

Gambar 2. Proses edting (dokumentasi: pribadi, 2019)

\section{Inovasi Rosette Guitar Quartet}

Seperti apa yang dijelaskan oleh Avanti Fontana (2011), ada 4 jenis inovasi, yakni; (1) Penemuan, (2) Pengembangan, (3) Duplikasi, dan (4) Sintesis. Tercapainya inovasi, berkat adanya pengenalan cara baru atau kombinasi baru dari cara lama dalam mentransformasi input menjadi output (teknologi) yang menghasilkan perubahan besar atau drastis dalam perbandingan antara lain guna yang dipersepsikan oleh konsumen atas manfaat suatu produk (barang dan/atau jasa) dan harga yang ditetapkan oleh produsen. Pernyataan di atas juga diimplikasikan oleh Rosette Guitar Quartet dalam proses kreatif seni serta berinovasi di era normal baru.

Bentuk inovasi yang dilakukan oleh Rosette Guitar Quartet sesuai yang dipaparkan oleh Avanti Fontana (2011), yaitu;

\section{Penemuan (Invention)}

Penemuan yang dilakukan oleh Rosette Guitar Quartet yaitu mengkreasikan suatu proses baru dalam pertunjukan musik dengan format grup guitar quartet di era normal baru. Penemuan tersebut yaitu yang membawakan lagu pada zaman postmodern dan diunggah di akun sosial media seperti You Tube dan Instagram. Proses atau karya baru ini dilakukan menyesuaikan kebiasaan baru dalam beraktifitas termasuk proses apresiasi dan ekspresi suatu karya seni musik.

\section{Pengembangan (Extention)}

Pengembangan Rosette Guitar Quartet yaitu memaksimal fungsi dari sosial media You
Tube dan Instagram sebagai sarana ekpresi dimana biasanya Rosette Guitar Quartet berekspresi dalam suatu gedung pertunjukan dan gedung resital yang bisa diapresiasi secara langsung dengan jumlah apresiator bisa mencapai 100 orang. Dengan jumlah penonton tersebut, akan sulit dilakukan pertunjukan di era new normal ini, karena kebiasaan di era new normal tidak boleh ada kerumunan massa, menjaga jaga jarak,s erta memakai masker. Rosette Guitar Quartet mengikuti kebiasaan baru ini, serta melakukan pengembangan dalam mengkespresikan karya mereka dalam sosial media, dimana para penikmat musik pada khususnya instrumen gitar bisa mengapresiasi dengan tenang dan nyaman karya dari Rosette Guitar Quartet di rumah atau dimana saja secara virtual.

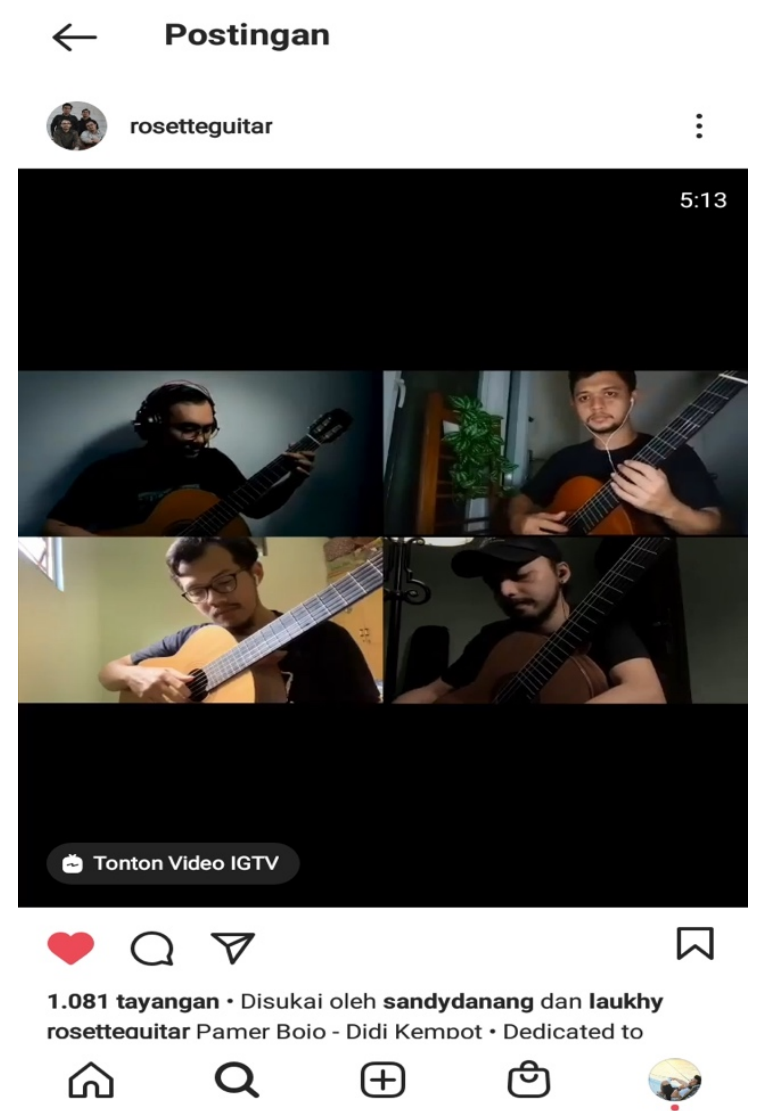

Gambar 3. Instagram sebagai media ekspresi (dokumentasi: pribadi, 2019)

\section{Duplikasi (Duplication)}

Duplikasi merupakan peniruan suatu produk, jasa, atau proses yang telah ada. Rosette Guitar Quartet melakukan duplikasi pada musisi yang terlebih dulu berekspresi dan memaksimalkan setiap karyanya dalam You Tube yang mendapat banyak apresiasi (viewers) 
serta mendapatkan komisi berupa uang tunai dari iklan yang mendukung dari tiap karya-karya yang diunggah di You Tube. Peluang besar ini dimanfaatkan oleh Rosette Guitar untuk berinovasi dalam proses kreatif pada setiap karya-karya barunya secara virtual di era new normal ini.

\section{Sintesis (Synthesis)}

Sintesis merupakan perpaduan konsep dan faktor-faktor yang sudah ada dan menjadi formula baru. Mengetahui peluang yang besar di sosial media You Tube, Rosette Guitar Quartet melakukan sintesis dengan membuat karyakarya baru tiap bulannya dan diunggah di You Tube. Proses kreatif dari sintesis ini dianggap oleh Rosette Guitar Quartet sebagai peluang besar dalam berkarya, berekspresi, serta berinovasi di era normal.

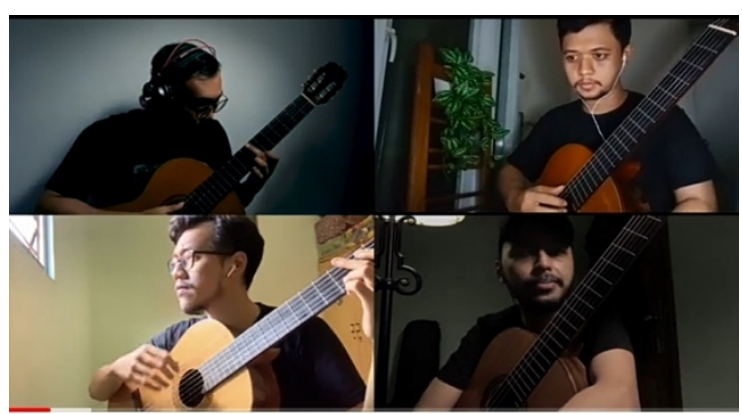

\#CollabJauh - Pamer Bojo (Cover) Tribute \& V Dedicated to Didi Kempot (1966-2020)

5.894 x ditonton $\cdot 6$ bulan lalu

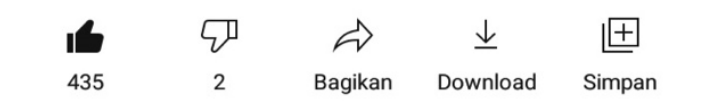

Rosette Guitar Quartet DISUBSCRIBE
48,7 rb subscriber

Gambar 4. Youtube sebagai sintesis dalam berkarya (dokumentasi: pribadi, 2019)

\section{KESIMPULAN}

Rosette Guitar Quartet adalah grup musik gitar yang terdiri empat orang yang berasal dari Surabaya. Repertoire yang dibawakan oleh Rosette Guitar Quartet adalah repertoire klasik dalam quartet gitar. Dewasa ini, serta pengaruh dari era new normal, Rosette Guitar melakukan beberapa inovasi dari karya (repertoire), proses seni kreatif, serta cara mengekspresikannya secara virtual melalui sosial media.

Rosette Guitar Quartet melakukan proses seni yang kreatif sesuai dengan yang dipaparkan oleh Damajanti tentang proses kreatif, yaitu; (1) Repertoire (lagu), (2) Aransemen, (3) Latihan dan "take audio", (4) "take video" dan "editing".
Proses kreatif yang dilakukan Rosette Guitar Quartet dengan menggunakan sosial media di era new normal ini menjadi peluang besar dalam berkarya, berekspresi, serta inovasi baru dalam kebiasaan-kebiasaan baru.

\section{DAFTAR PUSTAKA}

Anggraini, Nenny. 2008. "Industri Kreatif", Jurnal ekonomi Desember 2008 Volume XIII No. 3 hal.144-151.

Artanto, M. (2020). Pergelaran Simphoni Keroncong Moeda\# 9: Menimbang Ruang Antara Musik Dulu dan Kini. Virtuoso: Jurnal Pengkajian dan Penciptaan Musik, 3(1), 57-64.

Barker, C. (2004). Cultural studies: Teori \& praktik. Kreasi Wacana.

Fontana, Avanti. 2011. Inovate We Can!. Bekasi : Cipta Inovasi Sejarah.

Harjono, R., \& Rachman, A. (2018). Kreativitas Guru Dalam Pembelajaran Ekstrakurikuler Musik Keroncong Di SMP Negeri 1 Karangmoncol. Jurnal Seni Musik, 7(1), 34-47.

Maxwell Maltz. Psycho-Cybernetics: Update and Expanded. TarcherPerigee; Update, Expanded edition November 3, 2015)

Kusuma, S. R. (2019). Gaya Permainan Didiet Violin Dalam Lagu" Turning Point". Virtuoso: Jurnal Pengkajian dan Penciptaan Musik, 2(2), 106-120.

Strinati, Dominic. 2010. Populer Culture Pengantar: Menuju Teori Budaya Populer. Yogyakarta: Narasi

Sugiyono. 2011. Metode Penelitian Kuantitatif Kualitatif dan R \& D. Bandung: Alfabeta

Walidaini, B. (2020). Formula Latihan Teknik Tangan Kanan dalam Gitar Klasik: Shearer, Parkening, dan Werner. Virtuoso: Jurnal Pengkajian dan Penciptaan Musik, 3(2), 89-96. 